\title{
What is Locke's Theory of Representation?
}

\section{Walter Ott}

To cite this article: Walter Ott (2012) What is Locke's Theory of Representation?, British Journal for the History of Philosophy, 20:6, 1077-1095, DOI: 10.1080/09608788.2012.731234

To link to this article: https://doi.org/10.1080/09608788.2012.731234

\section{Published online: 30 Oct 2012.}

Submit your article to this journal ๔

Џlll Article views: 415

Citing articles: 3 View citing articles 두 


\title{
ARTICLE
}

\section{WHAT IS LOCKE'S THEORY OF REPRESENTATION?}

\author{
Walter Ott
}

\begin{abstract}
On a currently popular reading of Locke, an idea represents its cause, or what God intended to be its cause. Against Martha Bolton and my former self (among others), I argue that Locke cannot hold such a view, since it sins against his epistemology and theory of abstraction. I argue that Locke is committed to a resemblance theory of representation, with the result that ideas of secondary qualities are not representations.
\end{abstract}

KeYworDs: Locke; intentionality; representation; secondary qualities; externalism; meaning

\section{INTRODUCTION}

The answer to my titular question has come to seem obvious: Locke holds an externalist theory of representation. On such a view, what a simple idea of sensation represents is fixed by its connection to objects in a mindindependent world. ${ }^{1}$ Some externalist readings, such as those of Michael Ayers and Martha Bolton, take ideas to represent their causes. Others, such as that of Sally Ferguson, take ideas to represent what God intended to cause them. Despite these differences of detail, it is fair to say that the current orthodoxy reads Locke as a semantic externalist. ${ }^{2}$

To call this an attractive reading is an understatement. As Martha Bolton has argued, it insulates Locke from many of the attacks of his contemporaries, most notably George Berkeley. ${ }^{3}$ To ask how an idea can resemble a material object is just to miss the point of an externalist

\footnotetext{
${ }^{1}$ Throughout I shall be concerned only with simple ideas of sensation, or 'ideas' for short. Where other kinds of ideas are at issue, I shall flag this in the text.

${ }^{2}$ In a sense to be defined below.

${ }^{3}$ See M. Bolton, 'Berkeley and Mental Representation: Why Not a Lockean Theory of Ideas?', in New Interpretations of Berkeley's Thought, edited by Stephen H. Daniel (Amherst, NY: Humanity Books, 2008) 77-106. Bolton argues that all of Berkeley's arguments in the Principles beg the question against Locke by assuming a 'non-Lockean' theory of ideas, that is, an internalist theory of representation.
} 
semantics: what counts, where representation is concerned, is not whether the idea resembles its object but whether it has been caused by it. ${ }^{4}$ Moreover, the externalist reading anticipates recent developments in philosophy of mind. ${ }^{5}$ Locke thus emerges as a powerful and 'untimely' philosopher rather than an inconsistent and confused progenitor of Berkeley and Hume.

I wish the externalist reading were right, the more so as I have argued for it myself. ${ }^{6}$ I do not deny that the reading has strong support in the texts. But it makes nonsense of so many other of Locke's doctrines that it simply cannot be his considered view. This puts us in an uncomfortable predicament: either the evidence for the externalist interpretation must be read away, or else we must admit that Locke is, after all, deeply confused. I shall argue in the end for my own way through this thicket, a way that avoids the pitfalls of semantic externalism and returns resemblance to its role as the foundation of representation. Whether this positive proposal works will not, of course, affect the negative point: Locke cannot be a semantic externalist.

\section{THE TEXTUAL EVIDENCE}

Let us call a view 'externalist' if it endorses or entails the claim that what an idea represents (what it is an idea of) is fixed by features other than its intrinsic features. By an 'intrinsic' feature of an idea, I mean those features an idea has all on its own, independently of its relations to any other objects or acts. Given Locke's insistence on the transparency of the mental, ${ }^{7}$ intrinsic features will be those an idea can be seen to have through introspection. That an idea of a round table in some way includes the idea round can be seen simply by inspecting the idea. The most common feature externalists point to is, of course, the idea's causal origin: an idea is of a round object just in case it is caused by a round object. Now, an idea's causal history is not one of its intrinsic features: causal relations are paradigmatic cases of extrinsic features. Some, perhaps more sophisticated,

\footnotetext{
${ }^{4}$ In a recent paper (Hill, J. 'Berkeley's Missing Argument: The Skeptical Attack on Intentionality', British Journal for the History of Philosophy 19 (2011) No. 1: 47-77), Jonathan Hill argues for the centrality of resemblance in early modern accounts of representation. Perhaps a bit oddly, Hill barely mentions Locke, except to say that he thinks Locke rejects the resemblance theory (76). And although Hill does not discuss Bolton's very similar claims, he appears to agree with her that, insofar as Locke is among Berkeley's targets, Berkeley's arguments miss their mark.

${ }^{5}$ 'Recent' by historical standards, at any rate; see esp. Fodor, 'Semantics, Wisconsin Style', Synthese, 59 (1984) No. 3: 231-50. and and R.G. Millikan, Language, Thought, and Other Biological Categories (Cambridge, MA: MIT Press, 1984).

${ }^{6}$ See W. Ott, Locke's Philosophy of Language (Cambridge, UK: Cambridge University Press, 2004).

${ }^{7}$ I argue for this claim below.
} 
externalist views take teleology to be an essential ingredient in determining representation. On these views, an idea represents, not what in fact causes it on this or that occasion, but rather what is supposed to cause it. The 'supposed' here can be cashed out either in naturalistic terms, in which case it is a function of the evolutionary history of the subject's mental state, or in supernaturalistic terms, in which case it is a function of what God intended to bring about the idea.

Why think that Locke holds some version of externalism? Why should we think that a Lockean simple idea of sensation represents (what God intended to be) its cause? There are many texts that point in this direction, but there are two main sources for them: Locke's reply to veil of ideas skepticism in Book IV, and his discussion of the truth, reality, and adequacy of ideas in Book II. Let us begin with the latter.

All simple ideas of sensation are true. This can't literally be so, since ideas do not have propositional form: they do not claim that such-and-such is the case. Locke has in mind the truth or falsity of the claim that a given idea conforms to reality. In considering its ideas, the mind sometimes 'refers' its ideas to objects; 'in such a reference, [the mind] makes a tacit Supposition of their Conformity to that Thing: which Supposition, as it happens to be true or false; so the Ideas themselves come to be denominated' (II.xxxii.4: 385). ${ }^{8}$ The bar for such conformity in the case of simple ideas is very low. Indeed, even one who supposes that ideas are literally in objects can be said to have 'true' ideas. As Locke puts it,

Our simple Ideas, being barely such Perceptions, as God has fitted us to receive, and given Power to external objects to produce in us ... their Truth consists in nothing else, but in such Appearances, as are produced in us, and must be suitable to those Powers, he has placed in external Objects, or else they could not be produced in us: And thus answering those Powers, they are what they should be, true Ideas.

(II.xxxii.14: 388)

In the next section, Locke lays out his famous reply to the inverted spectrum problem. Even if a violet produced in Bobo's mind the color idea that a marigold produced in everyone else's, Bobo's simple ideas would not be false. For Bobo would 'be able as regularly to distinguish Things for his Use by those Appearances ... as if the Appearances, or Ideas in his Mind, received from those two flowers, were exactly the same, with the Ideas in other Men's minds' (II.xxxii.15: 389). Note that this solution assumes that ideas at least have a phenomenal content that can remain constant,

\footnotetext{
${ }^{8}$ References to Locke's Essay are to the edition of P. H. Nidditch (1975) and in the following format: Book.chapter.section: page number. References to Berkeley give the page numbers of the relevant volume in the Works of George Berkeley.
} 
regardless of the idea's role as a mark of differences among extra-mental objects.

Simple ideas of sensation are also 'real', or conform to their archetypes (II.xxx.1: 372). The kind of conformity Locke has in mind seems to be merely causal. Even ideas of secondary qualities, which resemble nothing in objects, are real, for they are

... in us the Effects of Powers in Things without us, ordained by our Maker, to produce in us such Sensations; they are real Ideas in us, whereby we distinguish the Qualities, that are really in things themselves. For these several Appearances, being designed to be the Marks, whereby we are to know, and distinguish Things, which we have to do with; our Ideas do as well serve us to that purpose, and are as real distinguishing Characters, whether they be only constant Effects, or else exact Resemblances of something in the things themselves: the reality lying in that steady correspondence, they have with the distinct Constitutions of real Beings.

(II.xxx.2: 373)

Finally, simple ideas are also adequate. All this adds to their truth and reality is the claim that they 'perfectly represent' their Archetypes (II.xxxi.1: 375). To support this, Locke re-states the claim that simple ideas of sensation are "nothing but the effects of certain Powers in Things, fitted and ordained by GOD, to produce such sensations in us' (II.xxxi.2: 375). God intended simple ideas of sensation to serve as marks or signs of objects or their powers, and this semiotic function is underwritten by the causal connection between sign and signified. ${ }^{9}$

Why think that all this talk of truth, reality and adequacy amounts to representation? As we have just seen, Locke explicitly says that simple ideas represent their archetypes. Even more clearly, he says that each simple idea is 'suitable to the Power that produced it, and which alone it represents'

\footnotetext{
${ }^{9}$ In 'Locke's Problem Concerning Perceptual Error', (LoLordo, A. 'Locke's Problem Concerning Perceptual Error', Philosophy and Phenomenological Research, 77 (2008) No. 3: 705-24), Antonia LoLordo argues persuasively that no analysis of the claim of the truth, reality, and conformity of Lockean ideas of sensation can be made coherent. Roughly, the problem is that if the claim (p) that all simple ideas are real (or true, or adequate) is taken as referring merely to tokens of those ideas and objects, then it is trivially true; but then it cannot bear the epistemic weight Locke puts upon it. (It would not guarantee the reliability of our sensory faculties, for example.) If (p) is read as referring to idea and object types rather than tokens, as Locke seems to intend, then it is obviously false, given the possibility of perceptual error. Finally, if (p) is read as the claim that all idea types are real just in case they correspond to object types in normal conditions, then it is too weak, for Locke claims that all simple ideas of sensation are real, not just those formed under certain conditions. An advantage of the teleological reading is that it can cash the check issued by 'normal conditions' in this last reading: normal conditions are precisely those God intended to obtain when a given idea type is tokened. But LoLordo's point still stands: Locke's formulations never restrict the claims of truth, reality, and adequacy of simple ideas to certain sets of conditions.
} 
(II.xxxii.16: 390). So simple ideas represent powers. And they can do this precisely because those powers cause them.

Unfortunately, Locke also says, in these same pages, just the opposite. Locke is careful to say that the claim that all simple ideas are real is not to be taken as the claim that 'they are all of them Images, or Representations of what does exist' (II.xxx.2: 372); indeed, he claims he has already proven the contrary in the case of secondary qualities. So Locke, at least in this text, denies that simple ideas represent their objects, and he denies this precisely because he takes representation to be resemblance. We shall return to this point below.

The other set of texts the externalist reading can point to comes from Book IV. On Locke's official definition, knowledge is the perception of the agreement or disagreement of ideas. Anticipating the veil of ideas objection, Locke recognizes that his reader will at this stage be wondering whether he has not been building 'a Castle in the Air': if all knowledge terminates in ideas, how can we ever be sure that our knowledge in fact reaches out to things in the world? To answer this, Locke introduces a distinction between knowledge and 'real knowledge'. Real knowledge obtains, not merely when ideas are perceived to agree or disagree, but when 'there is a conformity between our Ideas and the reality of Things' (IV.iv.3: 563). How can we tell when there is such a conformity? As Locke puts it, 'what shall be here the Criterion'? In the case of several kinds of ideas, we can be sure of such conformity:

The first [such kind of ideas] are simple Ideas, which, since the Mind, as has been shewed, can by no means make to it self, must necessarily be the product of Things operating on the Mind in a natural way, and producing therein those Perceptions which by the Wisdom and Will of our Maker they are ordained and adapted to, From whence it follows, that simple Ideas are not fictions of our Fancies, but the natural and regular productions of Things without us, really operating upon us; and so carry with them all the conformity which is intended; or which our state requires: For they represent to us Things under those appearances which they are fitted to produce in us: whereby we are enabled to distinguish the sorts of particular Substances, to discern the states they are in, and so to take them for our Necessities, and apply them to our Uses.

(IV.iv.4: 564; cp. II.xxx.2: 372-3)

Locke is offering an argument for thinking that ideas conform to objects in the world. This argument naturally avails itself of the reality of ideas established in Book II: what ties an idea to its object, it seems, is its role as a sign or mark of the powers of that object. Texts such as these strongly indicate that Locke holds an externalist view where it comes to semantics, if not epistemology: it seems clear that Lockean simple ideas represent their causes. ${ }^{10}$ We can now turn to the most influential attempts to articulate that view.

\footnotetext{
${ }^{10}$ In 'Berkeley and Mental Representation', Bolton argues that Locke endorses an externalist theory of justification, as well as an externalist semantics. While I disagree with this interpretation of Locke's epistemology, that is an argument for another day.
} 


\section{THE EXTERNALIST READING}

We can usefully distinguish those views that take Lockean representation to be causation from those that emphasize the teleological elements of his view. Roughly, the second camp takes an idea to represent what God intended to cause it, while the first camp just identifies representation with causation.

Such an identification seems to capture Michael Ayers's view. 'For Locke', he writes, 'this relation [i.e. causation] constitutes the basic representative relation: it determines what the idea represents'. ${ }^{11}$ Ideas, then, become elements in 'a natural language of thought'. ${ }^{12}$ This picture seems familiar enough, even if its elaboration requires considerable further refinements: an idea of type $\mathrm{G}$ is caused by objects of type $\mathrm{F}$; it then represents F-objects, where ' $\mathrm{F}$ ' is a characterization of the object's power to produce G-ideas. The mind can then use a token G-idea to represent a token F-object even when no object is at that moment causing that idea-token. There is an epistemic element at work as well, according to Ayers, for it is in virtue of the causal relationship that an occurrence in sensation of a G-idea serves as a sign or indication of an F-object. As Ayers puts it, '[t]he epistemological sign [of a power in an object] is also the semantic sign of this quality'. ${ }^{13}$ Bolton rightly points out that the epistemic role of a simple idea of sensation presupposes an independent means of conceiving of what is signified: I can hardly infer to $b$ from a if $I$ have no means of representing b. ${ }^{14}$ Ayers's view (at least on this interpretation of it) is in danger of sinning against Locke's anti-innatism: if we must already have a way of representing that which signs indicate, then indication cannot explain representation.

Addressing just this point, and explicating what I took to be Ayers's view, I wrote in 2004: 'Unsurprisingly, the causal connection that funds indicative sign inferences in the case of simple ideas also accounts for their role as representations. The epistemic function of ideas presupposes a distinct means of representing what is indicated; causal co-variance provides this means ...' ${ }^{15}$ To complain that Ayers's Locke lacks a means of representing the thing signified by an idea of sensation is to miss the point of the causal reading: it is one and the same relation, viz. causation, that makes an idea represent what it does and that funds inferences from the representation to the represented. For Ayers, then, signification and representation are only

\footnotetext{
${ }^{11}$ Ayers, M. R. Locke: Epistemology and Ontology, 2 vols (London: Routledge, 1991). vol. 1, 40; italics in original.

${ }^{12}$ Ayers, Locke, vol. 1, 62.

${ }^{13}$ Ayers, Locke, vol. 1, 38. Ayers holds that a simple idea of sensation is "naturally fitted to represent or "signify" in thought that feature of real things, whatever it may be, which is in general responsible for our receiving ideas or sensations of that type' (ibid.) Thus Ayers takes 'signify' and 'represent' to be interchangeable.

${ }^{14} \mathrm{M}$. Bolton, 'Locke on the Semantic and Epistemic Roles of Simple Ideas of Sensation', Pacific Philosophical Quarterly, 85 (2004) No. 3: 309.

${ }^{15} \mathrm{Ott}$, Locke's Philosophy of Language, 22-3.
} 
conceptually distinct; indeed, he uses them interchangeably. ${ }^{16}$ We can call this the 'pure' causal reading.

Unfortunately, it is unclear whether this reading accurately characterizes Ayers's view. For Ayers also holds that ideas are 'blank effects' that lack intentionality. They do not of themselves 'point to' things in the world; it is only when made the object of a judgement that they acquire representational powers. The mind has to take an idea to conform to the world, or 'tacitly refer' it to an object, in order for it to become a representation. We can call this the 'propositional' causal reading, to flag the fact that it is only when made the object of a judgement to the effect that such-and-such an idea has been produced by suchand-such an object that the idea acquires representational powers. In contrast with the pure causal reading, signification comes apart from representation. The idea does not represent its cause until the mind 'refers' the idea to the object. On its own, the idea is merely a blank effect or 'natural sign'. It does not become an intentional sign - i.e. a representation - until it is an element in a judgement of the mind. This seems to be how Bolton reads Ayers. ${ }^{17}$ I have no wish to bog down in commentary on the commentators, but it is worth getting these two views on the table, whichever ends up belonging to Ayers.

For her part, Bolton rejects the propositional causal reading, since, on her view, it lacks the resources to answer the charge of innatism. Again, I can only refer an idea to an object if I am already in possession of the concepts of objects, causes, and effects. ${ }^{18}$ This, of course, up-ends Locke's epistemology: we are supposed to start with simple ideas of sensation and boot-strap our way up to the ideas of power, cause, object, and so on. Thus in place of the propositional causal reading, Bolton offers a version of the pure causal reading. As she puts it, ideas have 'representative content in virtue of two conditions: (i) a steady causal link between ideas and their objects; (ii) an essential marking ${ }^{19}$ function in execution of which simple ideas are taken to convey something (rightly or wrongly) about the objects to which they direct notice, namely, their individual and qualitative differences and similarities' ${ }^{20}$ On this position, an idea of sensation represents its cause and of itself informs us of the existence of objects outside of us.

The second camp acknowledges that ideas of sensation always co-vary with their causes but denies that this co-variance is exhaustive of the

\footnotetext{
${ }^{16}$ See e.g. Ayers, Locke, vol. 1, 38, where Ayers claims that a simple idea 'is naturally fitted to represent or "signify" in thought that feature of real things, whatever it may be, that is in general responsible for our receiving sensations of that type'.

${ }^{17}$ Bolton, 'Locke on the Semantic and Epistemic Roles of Simple Ideas of Sensation', $309 \mathrm{f}$.

${ }^{18}$ Bolton puts the point well in 'Locke on the Semantic and Epistemic Roles', 310: 'An act of referring to something as the cause of an idea could be performed only by a mind that already possesses ideas of cause and effect. But Locke's anti-innatism requires him to extract all such representational content from simple ideas of sensation'.

${ }^{19}$ It is not clear whether Bolton intends to draw a distinction between marking and signifying. Locke, in any event, uses them interchangeably: see my Locke's Philosophy of Language.

${ }^{20}$ Bolton, 'Locke on the Semantic and Epistemic Roles', 316.
} 
representation relation. On the view articulated first by Sally Ferguson and then myself, it is not what causes an idea that counts but rather what God intended to cause the idea. The chief advantage teleosemantics can claim over purely causal theories is its ability to deal with misrepresentation: a token of a G-idea misrepresents its object as being $\mathrm{G}$ just in case it is caused by an object that is not in fact G. Similarly, a purely causal account (of either type canvassed above) faces the disjunction problem: if G-ideas can be caused by G-objects on some occasions, and by $\mathrm{H}$-objects on others, why not say that a G-idea represents (G-objects or H-objects)? The causal theorist has no good answer here, despite Jerry Fodor's strenuous efforts; ${ }^{21}$ the teleosemanticist can discount the competing disjuncts by zeroing in on the object that is supposed to cause the G-idea. The main puzzle for this sort of reading is that Locke never avails himself of these virtues, sticking to the claim that there is no such thing as misrepresentation where simple ideas are concerned. And yet, as we have seen from the texts, Locke seems to endorse the claim that an idea represents the object(s) that God intended to cause it.

There is no point in trying to adjudicate the debate between these two camps, for both are massively mistaken. Let us draw out what they have in common:

(a) What an idea represents is a function of its causal history. On the teleological variant, an idea is an idea of that object which God intended to cause it. On either sort of view, an idea's content is fixed by factors extrinsic to it.

(b) Whether an idea also resembles its object is a further question. Resemblance does not play the primary - or even $a$-role in fixing what an idea represents.

We can call (a) and (b) 'the externalist reading' to allow ourselves to abstract from the differences I have flagged in this section. I shall now argue that Locke cannot happily live with the consequences of the externalist reading. Many of the problems I shall point to are analogues of well-known difficulties with contemporary versions of semantic externalism. My point is not merely that Locke cannot answer these objections; arguably, neither can today's proponents of externalism. Rather, my claim is that, given his overall position, Locke cannot accept even the most easily seen consequences of externalism.

\section{WHY LOCKE CANNOT BE A SEMANTIC EXTERNALIST}

It would come as something of a shock to his contemporaries if Locke held (a) and (b) above. It is not just Berkeley who fails to pick up on the alleged

\footnotetext{
${ }^{21}$ See Fodor, 'Semantics'; for criticism, see Cummins, Meaning and Mental Representation (Cambridge, MA: Harvard University Press, 1989).
} 
semantic externalism of these wide swaths of the Essay; earlier commentators, such as John Sergeant and Henry Lee, who wrote much more thorough and sometimes chapter-by-chapter commentaries on the Essay, miss it as well. Perhaps there was nothing to miss.

At a minimum, we can say that semantic externalism comports ill with many of Locke's best-known positions. The points I shall make here fall into two main categories: those that involve epistemic access to our own ideas and those that concern Locke's official definition of knowledge. As I noted at the outset, the externalist view appeals to extrinsic features of an idea to ground out its representational powers. But any appeal to extrinsic features, such as causal history or teleology, comes at a high price.

There is good reason to think that Locke takes the representational contents of ideas to be transparent. Consider the difficulty Locke faces in explaining how it is that ideas can be confused. A confused idea is one that is not easily or readily distinguishable from another. But there seems to be no such idea. Given his definition of 'confused', Locke writes,

... it will be hard, may any one say, to find any where a confused Idea. For let any Idea be as it will, it can be no other but such as the Mind perceives it to be; and that very perception, sufficiently distinguishes it from all other Ideas, which cannot be other, i.e. different, without being perceived to be so. No Idea therefore can be undistinguishable from another, from which it ought to be different, unless you would have it different from it self: for from all others, it is evidently different.

(II.xxix.5: 364)

Locke's solution to the problem of confused ideas is to point to their relation to names: it is only the interposition of language that results in what may misleadingly be called a confused idea. But the chief point is that one is supposed to be able, through introspection of one's ideas alone, to discriminate one from another.

Prima facie, the externalist reading cannot make sense of this passage. If what fixes the representational content of an idea is its extrinsic relations, and if ideas are individuated by their contents (what they are ideas of), then there is no guarantee that, from the first person perspective, I am in any way entitled to say that two ideas are really two or in fact one. Now, some defenders of the externalist reading, such as Bolton, acknowledge that there is a phenomenal aspect to ideas, even though this is irrelevant to what they represent. (So much seems implied by the externalist take on the inverted spectrum passage.) If this is right, then it might turn out that my idea of round and my idea of square are in fact the same idea - they represent one and the same thing - even though they are phenomenally quite different.

Conversely, two phenomenally indistinguishable ideas might represent different features or kinds of objects. Take an idea of a secondary quality, say, blue. Now consider the intra-personal inverted spectrum, in which at 
time t my color experiences are inverted with respect to those of my former self. If the 'marking' function of blue shifts in this way, blue represents power $\mathrm{F}$ in objects before $\mathrm{t}$ and power $\mathrm{G}$ thereafter. ${ }^{22}$ Although my idea of blue remains phenomenally just as it always was, it is now, post-t, no longer an idea of blue. The externalist might deny that it is the representational content of ideas that individuates them. But this seems to me to be giving away the game: if ideas are not distinguishable by virtue of what they represent, how are they distinguishable at all? And what work would the idea's causal-cumteleological connections be doing, if not to individuate ideas?

We should keep in mind that in the case of simple ideas, nominal and real essences always coincide (III.iii.18: 418). Gábor Forrai takes this to mean that simple ideas are ideas of real essences out there in the world 'because their object is a single quality or power'. ${ }^{23}$ But this is confused: a real essence in a body is not a single quality or power but the hidden inner constitution of the thing. What Locke has in mind in saying that the real and nominal essence of a simple idea are one and the same is simply that there is nothing more to a simple idea than what is given in its nominal definition. There is no 'unknown Constitution' for a simple idea to hit or miss. Instead, 'the very being of any thing, whereby it is, what it is' (III.iii.15) is transparent, where simple ideas are concerned. This is hardly consistent with claiming that a simple idea represents something only in virtue of its extrinsic connections.

The first-person case has a second-person analogue: to know what your ideas are ideas of, that is, to know what ideas you have in mind on a given occasion, I would have to know a great deal about their causal history, or what God intended to cause them. In all his discussions of the pitfalls of communication in Book III, there is no hint that Locke thinks such knowledge of causes and divine goals is a pre-requisite for communication. ${ }^{24}$

The present problems are only the first signs of a much more serious one. Consider Locke's official definition of knowledge as 'nothing but the perception of the connexion and agreement, or disagreement and repugnancy of any of our Ideas' (IV.i.2: 523). ${ }^{25}$ There is no reason to think that the extrinsic features of an idea pointed to in (a) and (b) above are available to introspection; just the opposite, in fact. This is most stark on the teleosemantic reading: in order to know what an idea is an idea of, I have

\footnotetext{
${ }^{22}$ M. Bolton, 'Locke on the Semantic and Epistemic Roles', 315, points out that Locke thinks that ideas can be altered by judgement. In common cases of perceptual error, we can learn than an apparent ellipse is really a circle, for example (see II.ix.8). But this is not a case of an idea's content being altered by a shift in its cause.

${ }^{23}$ G. Forrai, 'Lockean Ideas as Intentional Contents', in Intentionality: Past and Future, edited by G. Forrai and G. Kampis (New York: Editions Rodopi, 2005) 47.

${ }^{24}$ In 'The epistemological objection to opaque teleological theories of content', in Teleosemantics, edited by David Papineau and Graham Macdonald (Clarendon: Oxford, 2006) 85-99, Frank Jackson mounts a similar argument against contemporary teleosemantics.

${ }^{25}$ In what follows, I leave aside sensitive knowledge, which Samuel Rickless has recently shown not be a form of knowledge at all. See S. Rickless, 'Is Locke's Theory of Knowledge Inconsistent?', Philosophy and Phenomenological Research, 77 (2008) No. 1: 83-104.
} 
to know what God intended to cause it. But it is equally clear on the causal variant: to know what an idea represents, I must first know what caused it. On either view, when an idea is (typically or always) caused by a new and different power in an object, as in our intrapersonal inverted spectrum case, its representandum shifts accordingly. This shift is not something that will be available to introspection. There is then no sense to be made of simply introspecting and perceiving the agreement or disagreement of two ideas. For all I know, my ideas of round and square, though from the phenomenal point of view incompatible, in fact represent the very same feature in objects and hence 'agree'. For all I know is the crucial phrase. Now, someone might be able to give an argument to show that it is impossible for these ideas to be caused by a single feature of an object. ${ }^{26}$ This is irrelevant to the question at hand, which is simply whether I can tell, solely by introspection, whether two ideas agree or not. The externalist's Locke must answer in the negative. But this is scarcely plausible.

The natural move for the externalist to make here is to appeal to Locke's distinction between knowledge and real knowledge. One can know that two ideas agree or disagree simply by looking at their phenomenal features; it is a further question whether those ideas conform to reality or not and so whether one is in possession of real knowledge or not. Fair enough. But even if we restrict ourselves to mere knowledge, and bracket the question of the ideas' conformity to the extra-mental world, we still have no means of accounting for knowledge as the perception of agreement or disagreement. If what an idea represents is not something to which I have epistemic access, I am in no position to say whether or not two ideas agree. This is assuming, of course, that whether ideas agree or disagree is a function of what they represent, i.e. what they are ideas of. But if this assumption is rejected, I no longer know what it could mean to define knowledge in the way Locke does.

In a similar vein, we might note that any logical connections that obtain among ideas must do so in virtue of their representational content. The kinds of supra-propositional connectives Locke considers in III.vii ('if', 'but', etc.) are used by the mind to indicate the connection it takes to obtain between propositions. But if what an idea represents is not among its introspectible features, there is no way to detect or make such connections. Suppose I formulate to myself the inference if this object is round, it cannot be square. Absent an awareness of what the ideas involved here mean, I cannot be sure that the logical connection between the propositions obtains. What is more important, absent such awareness, there is no way to explain why I am prompted to make the inference in the first place.

Finally, it is obscure how the externalist proposes to deal with Locke's account of abstraction. This has been the subject of much controversy, which I have no inclination to revisit. On any interpretation, Locke thinks

\footnotetext{
${ }^{26}$ In fact, just the opposite seems to be the case, as the tired example of the square tower that appears round from a distance demonstrates.
} 
that we select repeated features of our experiences and group them together under the heading of an abstract idea. This idea might be abstract in the sense that it does not include features possessed by the original ideas, or it might simply be one of those original ideas attended to selectively. In any case, the mind must have some way of zeroing in on a repeatable feature of the objects it experiences. How, on the externalist view, can one hope to do this? Again, I have no first-person access to what my ideas represent. Why think that the phenomenal feature I am isolating represents anything shared by the objects themselves? Note that I am not asking why we should think that we are tracking a single real essence: indeed, Locke denies that we are. But on the externalist's own view, simple ideas allow us to track powers in things, even if these powers supervene on radically different real essences in the objects that have them. So we ought to be able to formulate an abstract idea of, say, white that represents all and only things that have the power to produce that idea in us. But the externalist reading prevents us from doing so, since, again, there is no way to tell which power an idea is representing.

I have no doubt that such problems could be multiplied. The present suite of arguments should be enough, however, to make us wonder whether Locke really does hold any version of semantic externalism. The basic thrust of each argument is that externalism makes the introspectible features of ideas irrelevant to their logical and epistemic roles. And this conflicts with too much of Locke's view to be plausible.

\section{SEMANTIC INTERNALISM DEFENDED}

The evidence for the externalist reading seems overwhelming. And yet such a reading is untenable, or so I have argued. One tempting option is to declare that Locke is 'ahead of his time' in formulating some version of causal- or teleo-semantics; it should then not be a surprise that, as perhaps the first person to offer such a view in the modern period, he is deeply confused as to its implications.

This sort of approach is plainly a last resort. I believe we can do a bit better. My strategy will be to look more closely at the semiotic tradition in which Locke's discussions of the marking or signifying function of ideas fits. Once we do so, we shall find room for an interpretation that gives resemblance its appropriate role in founding representation. We shall then have the materials to account for Locke's treatment of simple ideas of sensations as marks or signs of their causes without importing externalism and without sinning against Locke's anti-innatism.

Before arguing for my view, let me take a first pass at articulating it. Consider again the text that seemed straightforwardly to conflict with the notion that an idea represents its cause (or what God intended to cause it): we should not think, according to Locke, that '[simple ideas] are all of them 
Images, or Representations of what does exist' (II.xxx.2: 372). This implies clearly enough that only some of our simple ideas are representations. If the only function of ideas of secondary qualities is to serve as marks or signs, perhaps they are not representations at all. This opens up a space for us to take ideas of primary qualities alone as representations. In such a case, it will be resemblance that grounds the representation relation. Ideas that do not resemble their objects are not representations, though they might still be signs.

Recall that, on either the pure causal reading (Bolton's view, and perhaps Ayers's as well) or the teleological account (Ferguson's and my own former views), signification or 'marking' gets identified with representation. But the semiotic tradition in which Locke stands would deny this identification: signification is one thing, representation another. Indeed, that tradition is mostly silent on how representation is achieved: it simply presupposes that there is some means of representing that which is indicated or signified, and concerns itself with how that indication is to be achieved. ${ }^{27}$

We should first distinguish reminiscent from indicative signs. A reminiscent sign is simply a reminder of something one has previously experienced. Through constant conjunction, it serves to lead the mind from one thought to another. In this way, smoke is a sign of fire. By contrast, an indicative sign points to something unobserved, or even unobservable. Commenting on a passage from Sextus Empiricus, Pierre Gassendi says that an indicative sign signifies that which is hidden 'because it is of such a nature that it could not exist unless the thing exists, and therefore whenever it exists, the thing also exists' ${ }^{28}$ Unlike a reminiscent sign, an indicative sign relies on a necessary connection between it and its significate. Gassendi's example here is sweat, which serves as an indicative sign of invisible pores in the skin.

When Locke calls ideas of sensation 'signs', it is clearly indicative signification that is at issue: one infers from the presence of the relevant idea to a power in an object. Locke also sees a necessary connection here. The 'truth' of such ideas 'consists in nothing else, but in such Appearances, as are produced in us, and must be suitable to those Powers, he [God] has placed in external Objects, or else they could not be produced in us: And thus answering those Powers, they are what they should be, true Ideas' (II.xxxii.14: 388; first emphasis mine). That a given idea token is 'suitable' to the power that produced it - a claim that is trivially true - does not mean that the idea represents that power. Indeed, we have already seen at least one text in which Locke sharply divides signifying or marking from representing, which is done by means of resemblance. And this is, I submit, just what we should expect.

On the internalist reading, then, although all simple ideas of sensation are marks or signs, only some of them are representations. Ideas of primary

\footnotetext{
${ }^{27}$ What follows is not intended to be a discussion of the entire semiotic tradition, which reaches back at least to Aristotle. For such a sketch, see chapter one of Locke's Philosophy of Language. ${ }^{28}$ P. Gassendi, Selected Works, edited by Craig Brush (New York: Johnson, 1972) 332.
} 
qualities represent their objects by resembling them, something ideas of secondary qualities cannot do. This sharp division between marking and representing fits well with the tradition that flows from Aristotle and Augustine through Sextus Empiricus through the Port-Royal Logic and Gassendi to Berkeley. To take just the last case, consider that, for Berkeley, 'everything we see, hear, feel, or any wise perceive' is a 'sign or effect of the Power of God'. ${ }^{29}$ At the same time, Berkeley of course insists that there cannot be an idea of God, or any spirit. ${ }^{30}$

Lockean simple ideas are all real, true, and adequate, even though only ideas of primary qualities are representations. In what sense, someone might object, can an idea of a secondary quality be 'true', if it is not a representation? It is not, as we have seen, the idea itself that is true or false but rather the judgement that it 'conforms to' an object. This conformity need not be representation: it is enough, Locke insists, that the idea stands in a causal relation to the object. The causal connection explains why the ideas of someone suffering spectrum-inversion are not false: their co-variance with the relevant powers of objects allows them to serve as signs. Although the mind naturally takes simple ideas to conform to their objects, or 'tacitly refers' them to objects (II.xxx.1: 372; see II.xxxii.4: 385), this is an inference, and one that requires further argument. ${ }^{31}$ Psychologically, one might say, the inference is all but unavoidable, from Locke's point of view; philosophically, it is controversial, and stands in need of argument.

There is a family resemblance between the internalist view I have defended and the propositional causal reading of Michael Ayers. To sum up: Ayers is wrong, on my view, to say that signification and representation are in effect the same thing, viz. causation. Ayers is right, however, to treat ideas of secondary qualities as 'blank effects', mental states that are not representations. They serve as marks or signs only when made the subject of a judgement, but even then they are not magically transformed into representations. Ayers is wrong once again to say that even simple ideas of primary qualities are blank effects; they can serve as signs but they can also, in virtue of resembling their objects, serve as representations.

By way of developing the internalist reading further, let me explain just how it entitles Locke to respond to the charge of innatism. In an intriguing article, Bolton locates a single argument in Berkeley's corpus that at least

\footnotetext{
${ }^{29}$ Principles of Human Knowledge I §148; cp. §65.

${ }^{30}$ See e.g. Principles I $\S 27$.

${ }^{31}$ See IV.iv.4: 564, quoted above, for the argument. Someone might object that Locke counts our awareness of the signification of signs as itself a kind of perception (II.xxi.5: 236), and that this undercuts my claim that it is an inference. But note that in this passage Locke is attributing 'perception' to the understanding; in just the same way, one can be said to perceive the logical connections among ideas. So being an act of perception in no way precludes a mental act from also being an inference. Berkeley preserves this usage, insisting that God is 'perceived' by means of his 'signs or effects' and yet denying that we have an idea of God (and therefore denying that we literally perceive God) (Principles I §148).
} 
seems directed at the externalist view. ${ }^{32}$ As she reads it, it identifies a key problem with Locke's externalist semantics. If I am to 'refer' my ideas to things, I need some independent way of representing those things. Berkeley's Locke is committed to innatism, malgré lui.

Near the end of the first Dialogue, Hylas suggests that he is able to use his ideas to think about matter in just the same way that a picture of Caesar represents Caesar. In neither case has the object represented been experienced by the subject, and yet the painting directs one's thoughts to its object. Why cannot we say the same about ideas? Philonous responds in part:

But to return to your comparison of Caesar's picture, it is plain, if you keep to that, you must hold that the real things or archetypes of our ideas are not perceived by sense, but by some internal faculty of the soul, as reason or memory. I would therefore fain know, what arguments you can draw from reason for the existence of what you call real things or material objects. Or do you remember to have seen them formerly as they are in themselves? ${ }^{33}$

As an argument against the pure causal theory, this is lame from the start. For the whole point of that version of externalism is that the sign just is the representation: there is no need to come up with some extra way of representing the significate. If signification and representation come apart in the way I have indicated, however, Philonous's argument gets a point: how is it that I am able to think of a world of mind-independent objects? If I am supposed to use my ideas to infer to an external world, I must first have a way of representing that world.

The internalist reading of Locke both makes sense of Berkeley's argument and allows Locke to reply. This reading accepts that signification is not representation and hence is not, by itself, enough to allow us to think of an external world. How, then, am I able to think of mind-independent objects? What I give below is merely a sketch that would have to be filled in, but should serve present purposes.

Locke's recipe begins with simple ideas of sensation. Among these one finds ideas of primary qualities. These resemble, and hence represent, their objects. This, together with the simple idea of space (II.xiii.2: 167), provides the thinkability of an external world. ${ }^{34}$ Since we can be sure that the primary qualities represented by simple ideas of sensation cannot flit about on their own, we generate, by means of a definite description, ${ }^{35}$ an idea of substance (II.xxiii.1: 295).

\footnotetext{
${ }^{32}$ Bolton, 'Berkeley and Mental Representation'.

${ }^{33}$ Three Dialogues between Hylas and Philonous I 204.

${ }^{34}$ Berkeley's New Theory of Vision is designed partly, of course, to undermine Locke's contention that we passively receive an idea of space in sensation.

${ }^{35}$ For Locke's use of definite descriptions, both in this case and in the case of real essences, see my Locke's Philosophy of Language. I disagree with Bolton's claim ('Locke on the Semantic and Epistemic Roles of Simple Ideas of Sensation', 310) that 'Locke's anti-innatism requires him to
} 
Next, we notice changes in the primary qualities of these substances and formulate our idea of power (II.xxi). Putting the ideas of space, objects, and power together, we can conceive of a world of objects with intrinsic primary qualities and with the powers to cause that other sort of simple idea we notice in sensation, viz. ideas of secondary qualities. We then tacitly refer all simple ideas to objects in the sense that we judge that they co-vary with the powers in objects that cause them. While not representations, ideas of secondary qualities are nevertheless useful tools provided by God to allow us to navigate through the world. Ideas of secondary qualities are mere marks or signs. But what they mark or signify is, just as the tradition (not to mention Philonous) maintains, something we have to have an antecedent way of representing. And that is precisely what our ideas of space, objects or substances, power, and primary qualities allow us to do. No tours through Plato's heaven need apply.

I have saved the most pressing worry for last. It is simply this: however persuasive the arguments of the previous section might be, the fact remains that Locke says over and over again that all simple ideas, even those of secondary qualities, are representations. I must, for example, read away the passage in which Locke says that an idea is 'suitable to the Power that produced it, and which alone it represents' (II.xxxii.16: 390). The first line of defense is $t u$ quoque: the externalist must read away the passage in which Locke says that not all ideas represent objects (II.xxx.2: 372), as well as the passages I discuss below, in which Locke explicitly ties representation to resemblance. If Locke is to have a consistent and plausible theory, some of his remarks must read away, and as long as we are in the business of finding a coherent interpretation, this is a price we shall all have to pay. What is more, my view can explain easily enough why Locke would sometimes speak as if ideas qua blank effects represented their objects: it is a natural enough lapse, given his view of the epistemic (though not representational) role of ideas of secondary qualities.

A more plausible defense can be mounted if we pay attention to the ways in which Locke uses 'representation' and its relatives. Among its eighty or so occurrences throughout the Essay, one can discern both a broad and a narrow use of 'representation'. In the broad sense, to represent is simply to make known in some way or other, or to exhibit something to one's attention. For example, Locke claims that a word can be defined by other words when 'the Idea it is made the Sign of, and annexed to in the Mind of the Speaker, is as it were represented, or set before the view of another' (III.iv.6: 422; see III.iv.12). Similarly, Locke writes that in a well-drawn picture, 'we readily say, this is a Lion, and that a Rose; this is a Gold, and that a Silver Goblet, only by the different Figures and Colors, represented to the Eye by the Pencil' (III.vi.29: 457). In the broad sense, 'representation' is 
not even a feature that exclusively mental states or objects can have: sounds or marks on a page can set many things 'before the view'. Now, given their role as marks or signs, simple ideas of secondary qualities can of course be said to 'represent' in this way. For God's purpose in setting matters up in such a way that we have these ideas is precisely to allow us to track features of the world.

There are also times in which Locke uses 'representation' in a stricter sense. This sense seems to map much more neatly on to contemporary uses of the term. In this sense, an idea represents, not just anything it can be used to draw our attention to, but what it is of. Representation in this sense requires resemblance. Already we have seen one text that does this (II.xxx.2: 372). There are others. For example, Locke writes that the collective idea of all bodies is a genuinely single idea, despite the fact that many things fall under it; it can 'be considered as one Representation, or Picture, though made up of never so many particulars' (II.xxiv.1: 318). 'Picture' here is clearly intended as a gloss on 'Representation', and the picturing relation requires resemblance. As a third instance, consider Locke's claim that ideas of substances are sometimes 'only design'd to be Pictures and Representations in the Mind, of Things that do exist, by Ideas of those qualities that are discoverable in them' (II.xxi.6: 378). We can conclude, then, that representation in the strict sense is not something simple ideas of secondary qualities can do. The mere fact that an idea gets used in a process by which we come to discern objective differences between objects does not make it a representation in the strict sense.

To all of this, our objector will reply that, in granting that Lockean ideas are representations in the wide sense, I have conceded the point to my opponents. There is now no substantive issue on which we disagree. But nothing could be further from the truth. On my view, representation in the strict sense - the of-ness of an idea - is limited to resemblance; as a consequence, ideas of secondary qualities are not of anything at all. This view alone lets us fit together Locke's claims about ideas with his views of knowledge, as I shall now argue.

\section{KNOWLEDGE AND REPRESENTATION}

By way of conclusion, let us go back and see how the internalist reading fares against the objections I lodged against externalism. The first set of complaints dealt with our inability, on the externalist view, to see just what our ideas represent. Plainly, this is no longer a worry: when an idea represents at all, its introspectible features alone determine what it represents. The issue of epistemic access does not arise with regard to ideas of secondary qualities: just as Ayers claims, they are blank effects. This is not to say that they have no introspectible features: the sensation of red, just like the sensation of pain, necessarily includes among its intrinsic features a 
feeling: in the tired phrase, a 'what it is like'. It is resemblance in this respect that makes such ideas capable of representing one another, as Locke's account of abstraction requires (II.xi.9: 159).

On the internalist reading, Lockean representation just is, as his contemporaries thought, resemblance. Now, the idea of red can resemble nothing in the object. But an abstract idea of red (however abstraction is effected) can, trivially, resemble other ideas of red. ${ }^{36}$ Ideas of secondary qualities can become representations in the strict sense when compared, not with objects, but with one another, where resemblance becomes unproblematic. But these abstract ideas will not be ideas as given in sensation but rather as used in thought. To be clear: the internalist reading says only that ideas of secondary qualities that are also simple ideas of sensation are not representations. So the present revision is not really a revision at all.

The second set of objections to externalism focused on knowledge. The internalist reading saves Locke's official definition of knowledge (again, sensitive knowledge aside). One can see through introspection that one's ideas of a circle and a square do not agree. Similarly, we can just see, through our 'raw feels', that the ideas red and blue do not agree. Although their agreement or disagreement is not a matter of their representational content - they have none - it nevertheless makes sense to say that they are distinct ideas, in virtue of the 'raw feels' that constitute them. By contrast, Bolton's externalist reading holds that simple ideas of secondary qualities $d o$ have representational content; the problem then was to see how one could perceive their (dis)agreement without access to that content through introspection. On the present view, there is nothing more to these ideas of secondary qualities than is revealed by introspection. Knowledge of their (dis)agreement is therefore rendered unproblematic.

To sum up: despite the manifest virtues and attractions of the externalist reading of Locke, it simply cannot be right. If it were, Locke would be even more befuddled than his most vitriolic critics typically allow. Although the externalist reading can award Locke points for anticipating contemporary views, it is, in light of the semiotic tradition that informs Locke's work, anachronistic. I have suggested an alternative reading, one that preserves his most characteristic doctrines and allows us to make good sense of the relevant passages. If Locke then becomes much more a figure of his age than our own, so much the better. ${ }^{37}$

Virginia Tech

\footnotetext{
${ }^{36}$ I argue in Locke's Philosophy of Language, 66, that even an Ayersian reading of representation requires a move like this.

${ }^{37}$ I would like to thank the editor of this journal. I am greatly indebted to Antonia LoLordo for helpful comments.
} 


\section{BIBLIOGRAPHY}

Ayers, M. R. Locke: Epistemology and Ontology, 2 vols (London: Routledge, 1991).

Berkeley, G. The Works of George of Berkeley (London: Nelson and Sons, 1946-57).

Bolton, M. 'Locke on the Semantic and Epistemic Roles of Simple Ideas of Sensation', Pacific Philosophical Quarterly, 85 (2004) No. 3: 301-21.

Bolton, M. 'Berkeley and mental representation: Why not a Lockean theory of ideas?', in New Interpretations of Berkeley's Thought, edited by Stephen H. Daniel (Amherst, NY: Humanity Books, 2008) 77-106.

Cummins, R. Meaning and Mental Representation (Cambridge, MA: Harvard University Press, 1989).

Ferguson, S. 'Lockian Teleosemantics', Locke Studies, 1 (2001): 105-22.

Fodor, J. 'Semantics, Wisconsin Style', Synthese, 59 (1984) No. 3: 231-50.

Forrai, G. 'Lockean ideas as intentional contents', in Intentionality: Past and Future, edited by G. Forrai and G. Kampis (New York: Editions Rodopi, 2005) 37-50.

Gassendi, P. The Selected Works of Pierre Gassendi, edited by Craig Brush (New York: Johnson, 1972).

Hill, J. 'Berkeley's Missing Argument: The Skeptical Attack on Intentionality', British Journal for the History of Philosophy 19 (2011) No. 1: 4777.

Jackson, F. 'The epistemological objection to opaque teleological theories of content', in Teleosemantics, edited by David Papineau and Graham Macdonald (Clarendon: Oxford, 2006) 85-99.

Locke, J. An Essay Concerning Human Understanding, edited by P. H. Nidditch (Oxford: Clarendon Press, 1975).

LoLordo, A. 'Locke's Problem Concerning Perceptual Error', Philosophy and Phenomenological Research, 77 (2008) No. 3: 705-24.

Millikan, R. G. Language, Thought, and Other Biological Categories (Cambridge, MA: MIT Press, 1984).

Ott, W. Locke's Philosophy of Language (Cambridge, UK: Cambridge University Press, 2004).

Rickless, S. 'Is Locke's Theory of Knowledge Inconsistent?', Philosophy and Phenomenological Research, 77 (2008) No. 1: 83-104. 